\title{
The scope of quantitative polymerase chain reaction assays in clinical molecular pathology
}

\author{
R D G Malcomson, C T McCullough, D J Bruce, D J Harrison
}

\section{Introduction}

Clinicians routinely look to a diverse selection of quantitative measures of biochemical parameters in various body fluids as a convenient means of assessing the disease state of patients. Values for electrolytes, metabolites and serological properties all provide information that may be useful in diagnosis, prognosis and in determining treatment of clinical conditions. Increasingly, more is being learned about the molecular basis of a wide range of diseases which, until recently, have been relatively poorly understood. Immunohistochemistry and in situ hybridisation have proved to be popular techniques in the qualitative investigation of patterns of gene expression in biopsy specimens. The molecular pathologist's role in clinical diagnostics is expanding and increasingly requires rapid and reliable means of quantifying the levels of various key molecules (for example, amplified genes, viral genomic DNA or specific mRNA species).

In clinical investigations, specific protein concentrations in the serum do not necessarily correlate with concentrations found in diseased organs and do not provide information about the localisation of the main source of the measured gene product. In addition, molecules that may be important indicators of diagnosis or prognosis of neoplastic or inflammatory lesions are often localised to the disease site and may not be measured usefully by a serological test. Molecular analysis of small pieces of biopsy material may therefore provide more useful information.

The methods of choice for monitoring molecular parameters such as viral load, gene copy number and gene expression have been generally regarded to be those that involve some form of "blotting" procedure. Nucleic acids can be quantitated readily by these methods. Additionally, a large number of proteins can be quantitated rapidly by enzyme linked immunosorbent assay (ELISA). However, the requirement by these methods for large or fresh samples limits their use and attractiveness to the molecular pathologist who will probably be presented with only small amounts of material with which to work. In the future, sample size will become more important as minimally invasive biopsy procedures become more popular, resulting in less material becoming available for molecular investigations.

The alternative approach to quantitation of molecules by blotting or ELISA involves the polymerase chain reaction (PCR) which, because of its extreme sensitivity, permits the use of small samples such as those taken from fine needle biopsies or aspirates. Where com- parisons with hybridisation analyses have been possible, results of quantitative PCR (qPCR) reactions are comparable. ${ }^{123}$ Less than 10 copies of target sequence are required for a PCR reaction and it is possible to amplify from material extracted from single cells. ${ }^{4}$ In addition, nucleic acid preparation procedures can be modified to permit the use of fixed and paraffin wax embedded material, thus permitting analysis of archival material. ${ }^{56}$

In this article we present an overview molecular quantitation by PCR from practical and clinical viewpoints. Examples are given and some of the factors that affect quantitation of DNA or RNA are discussed.

\section{Quantitative PCR: the technology}

When designing a qPCR assay, three major considerations must be taken into account. These considerations arise as a result of features peculiar to the qPCR reaction that generally do not substantially affect the results of qualitative PCR assays. They are: (1) variations in amplification efficiency between reaction tubes; (2) the plateau effect; and (3) loading errors.

\section{AMPLIFICATION EFFICIENCY}

Because the number of product molecules increases exponentially with thermal cycle number, small changes in amplification efficiency between sample tubes can have a profound effect on the final concentration of reaction products. One way of dealing with this problem is to coamplify a predetermined quantity of a competitor template with each target template. In parallel reactions, a constant amount of the same sample is spiked with a series of known concentrations of competitor. If the two templates are shown to amplify at similar rates (the slopes of plots of $\log$ product concentration against cycle number for each template are similar), then the competitor concentration that produces equimolar competitor and target product concentrations is indicative of the level of target sequence in the sample (competitive $\mathrm{PCR}^{78}$ ) (fig 1). The use of RNA as opposed to DNA competitors can be used to control for reverse transcriptase variations in quantitative reverse transcriptase PCR assays. ${ }^{910}$

The competitor products must be in some way distinguishable from the target products (for example, inclusion of a small intron ${ }^{11}$ or modifications made by recombinant methods ${ }^{9-13}$ ). The most reliable choice of competitor is that in which the sequence difference is as small as possible (for example, modification of a restriction site by end fill-in or by site-dir- 

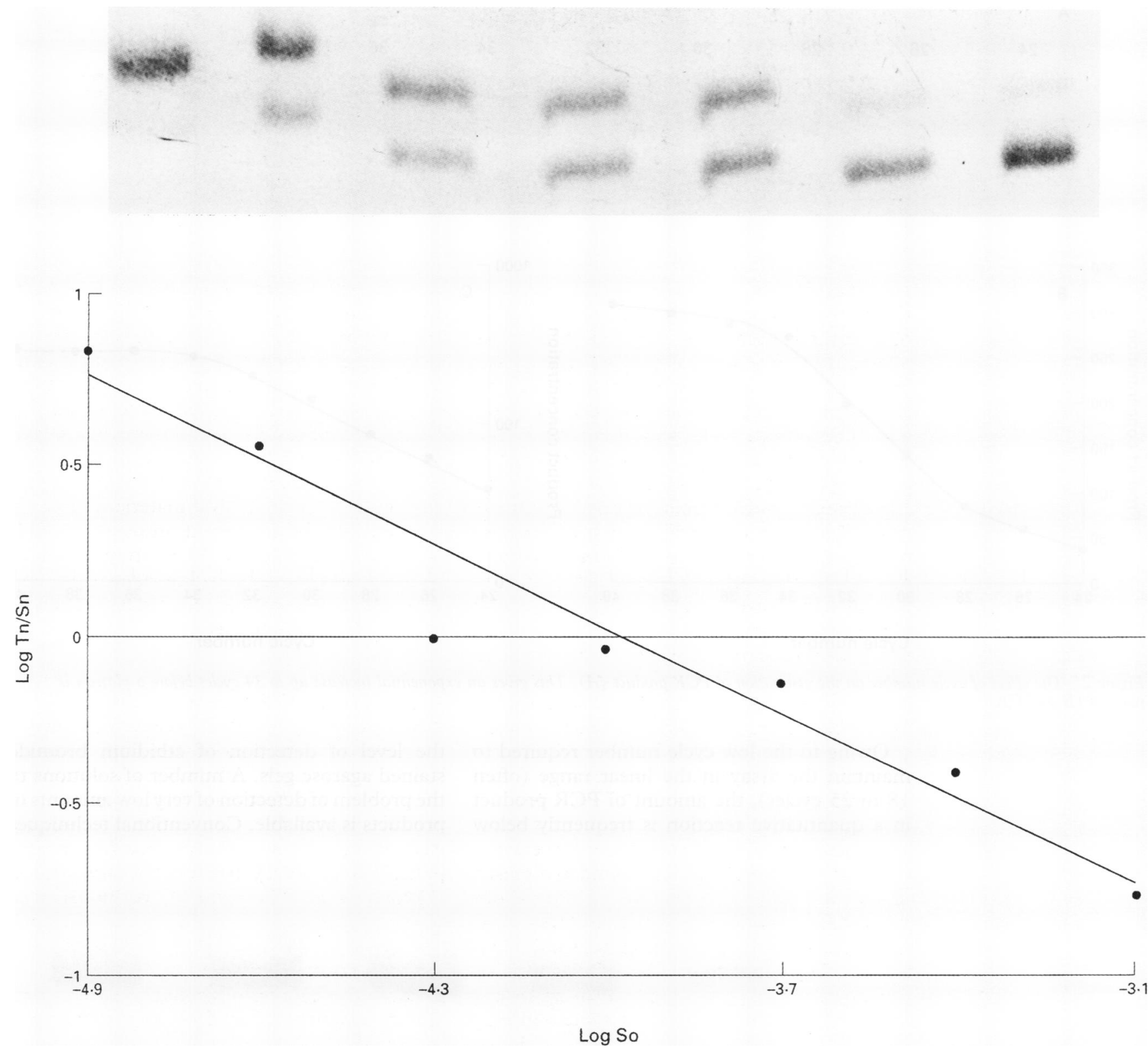

Figure 1 Competitive PCR using an exogenous standard which is a modification of the target template produced by the insertion of four base pairs by filling in an internal restriction enzyme cleavage site with Klenow fragment. The upper panel shows the effect of serial twofold dilutions of the exogenous standard (upper bands) on the relative amplification of the target sequence. The graph is a logarithmic plot of the ratio of band intensity against the concentration of the standard. The gradient of the slope approximates to $-1 \cdot 0$, as would be expected from theory.

ected mutagenesis of the cloned target product). These conservative changes are less likely to cause differences in amplification efficiency between the two templates than large insertions or deletions. However, competitor templates that contain a region of exogenous sequence between the two primer recognition sequences (PCR mimics) have been used successfully and can reduce the problem of heteroduplex formation between template and competitor amplimers. These synthetic competitors can be constructed so that they are multifunctionalthat is, they have multiple primer recognition sequences and can be used to quantitate the expression of a number of different genes. ${ }^{9}$

THE PLATEAU EFFECT

The PCR does not continue in its exponential phase indefinitely. Reagents are consumed, there is generation of the polymerase inhibitor pyrophosphate and a decrease in activity of Taq DNA polymerase during the course of a PCR run. All of these factors affect the graph of the log product concentration against cycle number which becomes non-linear (plateau phase) and reaches a maximum at high cycle number ${ }^{14}$ (fig 2). This effect can be eliminated simply by terminating the reaction at a point where the increase in product concentration is still exponential (that is, before the plateau phase). The point at which the reaction becomes saturated must be determined experimentally so that any particular sample has a template concentration that remains within the quantifiable range of the assay. Non-competitive PCR assays rely on the fact that prior to the plateau phase the amount of product molecules varies linearly with amount of template put into the reaction ${ }^{15}$ (fig 3 ). These procedures, however, do not have internal controls for intertube variability or loading. 
A
24
26
28
30
32
34
36
38
40
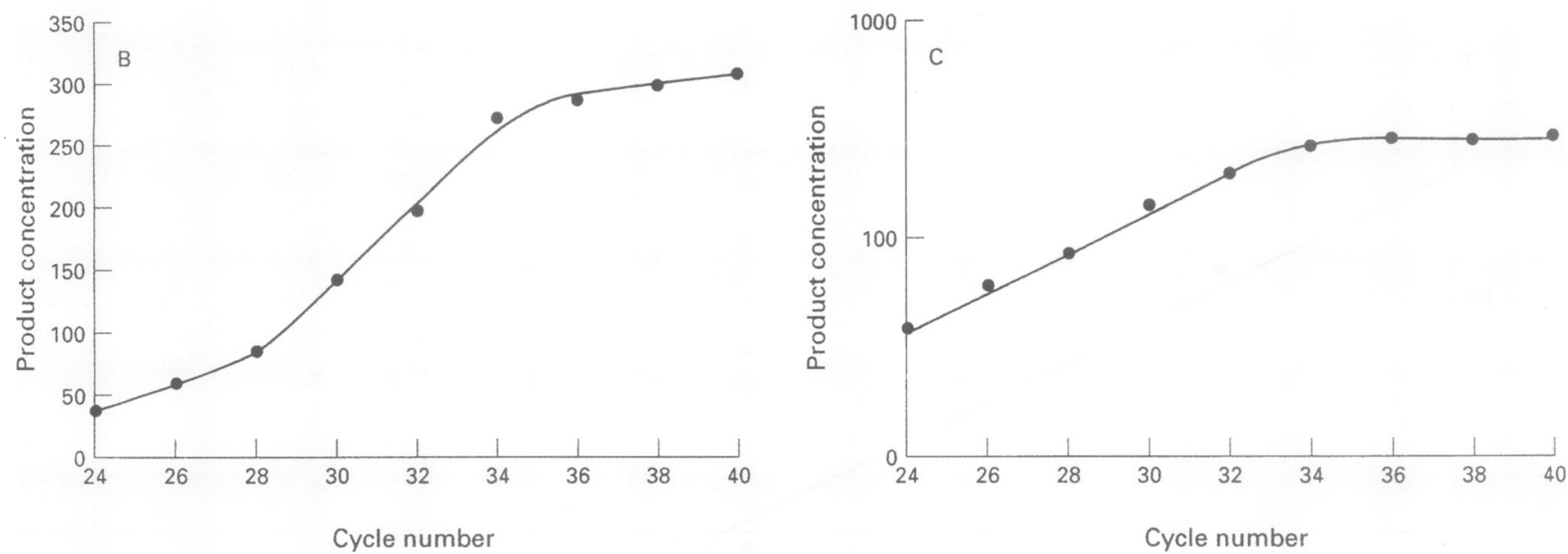

Figure 2 The effect of cycle number on the generation of PCR product $(A)$. This gives an exponential increase up to 34 cycles before a plateau is reached $(B$ and $C)$.

Owing to the low cycle number required to maintain the assay in the linear range (often 18 to 25 cycles), the amount of PCR product in a quantitative reaction is frequently below the level of detection of ethidium bromide stained agarose gels. A number of solutions to the problem of detection of very low amounts of products is available. Conventional techniques

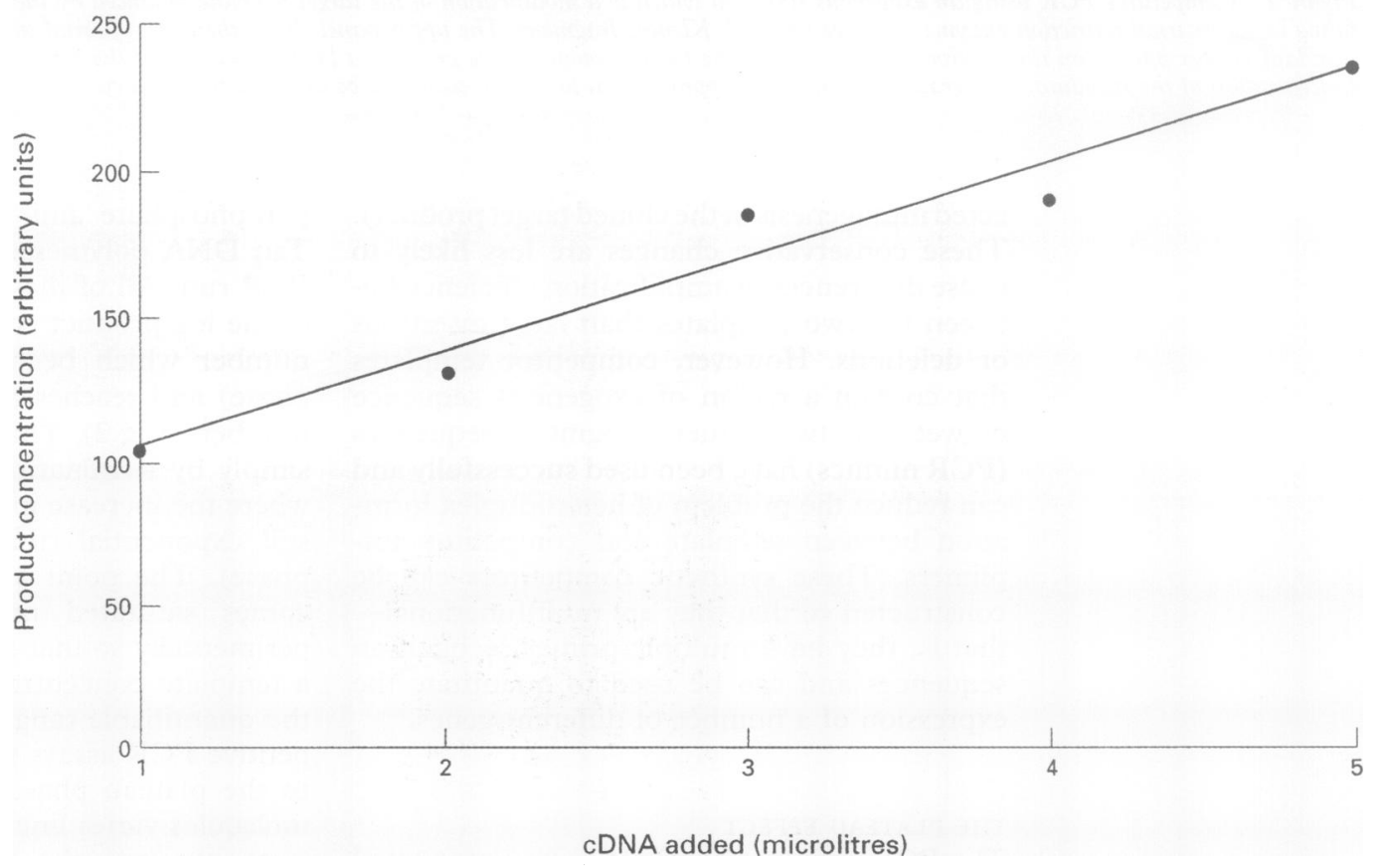

Figure 3 Non-competitive PCR demonstrating that the amount of product is directly proportional to the initial quantity of target sequence, which was varied by serial dilution of $c D N A$. 
such as Southern blotting of the products ${ }^{16}$ and densitometry (or better-phosphor-imaging) of incorporated radiolabel or high pressure liquid chromatography have their drawbacks for quantitative assays but are used widely, especially in semiquantitative assays. Newer techniques are more applicable to the safe, highly sensitive and rapid analysis of qPCR samples in the clinical laboratory. These include detection of fluorescent labels in automated detection systems such as a DNA sequencer or detection of products in solution hybridisation by magnetic bead separation and electrochemiluminescence. ${ }^{17}$

\section{LOADING ERRORS}

Inaccuracies in the amount of starting material as measured by total RNA or DNA concentrations are important variables that affect quantitation. In northern blot analysis, hybridisation with a second probe specific for a "housekeeping" reporter gene (often $\beta$-actin or G3PDH) acts as a control for both loading and RNA degradation. Similarly, in qPCR assays, amplification of a second gene can control for these factors, assuming that both PCR assays remain in the quantitative phase of amplification. ${ }^{1819}$ The ratio of the target product concentration to the control product concentration is taken as a measure of the initial amount of the target sequence in the sample (differential PCR). Ideally, coamplification of the two sequences should be performed in a single reaction vessel but there should be awareness that the two amplimers may compete in some instances. ${ }^{20}$

By combining both differential and competitive PCR in a single reaction vessel (two competitive PCRs, one for the gene of interest and one control), substantial enhancements to the reproducibility and accuracy of quantitations can be made. ${ }^{12}$

Preparation of sample DNA or cDNA template In addition to the general precautions taken to ensure that all samples should not be crosscontaminated or contaminated with products before amplification by PCR, protocols should be adopted that ensure that the preparation of sample template is performed in a reliable and reasonably consistent fashion. The protocols used routinely for the extraction of DNA and RNA from formaldehyde fixed and paraffin wax embedded tissue samples in our laboratory are outlined below. Further, if mRNA expression is being analysed, the protocol for reverse transcription of mRNA to cDNA should be efficient and reasonably consistent. We use synthetic oligo [dT] or random hexamers to prime reverse transcription with RNAse $\mathrm{H}^{-}$MoMLV Reverse transcriptase (Superscript II from Life Technologies). In order to limit mispriming in the first thermal cycle of quantitative PCR reactions, which can affect the reproducibility and accuracy of quantitation, a "hot start" technique ${ }^{21}$ is used.
Protocol for extraction of DNA from paraffin wax embedded tissue sections ${ }^{5}$

A $10 \mu \mathrm{m}$ section of paraffin wax embedded tissue is placed in a microcentrifuge tube and incubated at $55^{\circ} \mathrm{C}$ with buffer $\mathrm{A}(50 \mathrm{mM} \mathrm{KCl}$, $2.5 \mathrm{mM} \mathrm{MgCl} 2,20 \mathrm{mM}$ Tris- $\mathrm{HCl}$ (pH 8.0), $0.45 \%$ NP-40, $0.45 \%$ Tween-20) and $200 \mu \mathrm{g} /$ $\mathrm{ml}$ proteinase K. Samples are then boiled for 20 minutes before storage at $4^{\circ} \mathrm{C}$. DNA concentrations of sample are estimated by spectrophotometry and 100-300 ng of DNA (made up to $15 \mu \mathrm{l}$ in buffer $\mathrm{A}$ ) is used per $100 \mu \mathrm{l}$ PCR reaction. There should be enough DNA yielded using this technique for 30-50 PCR assays. Best results are obtained when samples are subjected to PCR within one to two weeks of extraction.

\section{Protocol for extraction of $R N A$ from paraffin} wax embedded tissue sections (based on Miens) A $20 \mu \mathrm{m}$ section is deparaffinised twice in $400 \mu$ l of xylene for 15 minutes and pelleted. The section is then washed in $400 \mu$ l absolute ethanol and RNA is extracted from the tissue pellet with $300 \mu \mathrm{l}$ TRIOL (Life Technologies) (dissolved by vortexing and incubated on ice for five minutes) and $30 \mu \mathrm{l}$ chloroform and precipitated with one volume of isopropanol on ice for one to three hours. The RNA is then collected by centrifugation at $4^{\circ} \mathrm{C}$ for 15 minutes, washed with $200 \mu \mathrm{l} 75 \%$ ethanol, briefly vacuum dried (no more than five minutes) and then redissolved in $50 \mu$ diethyl pyrocarbonate treated deionised distilled water (DEPC/DDW). Total RNA concentration is determined by spectrophotometry and $1 \mu \mathrm{g}$ RNA diluted to $5 \mu \mathrm{l}$ with DEPC/DDW is used in a $20 \mu \mathrm{l}$ reverse transcription reaction prior to PCR.

\section{Quantitative PCR: clinical applications}

Quantitative PCR has a wide range of applications in the clinical context. It has proven especially valuable in evaluating certain viral infections as PCR enables rapid and highly specific diagnosis and titration. Many other applications of qPCR are in use or are being evaluated and promise to be valuable tools in diagnosis and in the direction of treatment strategies. For example, quantitative analysis of viral genomic RNA or proviral DNA provides a good indication of the disease stage in HIV infection ${ }^{1322-24}$ and can mark the transition from clinical latency to the active replication stage. ${ }^{25}$

Used in conjunction with minimally invasive sample collection procedures, molecular parameters can be monitored throughout the course of a disease and its treatment (for example, in monitoring of bone marrow transplants for molecular markers of transplant rejection ${ }^{26}$ or opportunistic infections in immunosuppressed patients ${ }^{27}$ ).

It is not necessary in every application of qPCR to provide absolute quantitation. In cases where allele loss determinations, percentage residual cell content or relative levels of cytokines are required, it may be sufficient to perform a simple differential PCR assay 
A summary of some of the reports published in the literature detailing the use of PCR in clinical practice

\begin{tabular}{|c|c|c|c|c|}
\hline Disease type & Situation & Sequence amplified & Use $(s)$ & Reference (s) \\
\hline \multirow[t]{8}{*}{$\begin{array}{l}\text { Infections } \\
\text { viral }\end{array}$} & CMV & $\begin{array}{l}\text { CMV glycoprotein } \mathrm{H}(\mathrm{gH}) \\
\text { DNA }\end{array}$ & Monitoring CMV infection in immunosuppression & 27 \\
\hline & EBV & EBV EBNA-1 DNA & EBV associated lymphoproliferation in immunosuppression & 29 \\
\hline & HBV & HBV $S$ gene DNA & Monitoring $\mathrm{HBV}$ infection & 30 \\
\hline & $\begin{array}{l}\mathrm{HCV} \\
\mathrm{HDV}\end{array}$ & $\begin{array}{l}\text { HCV genomic RNA } \\
\text { HDV viral DNA }\end{array}$ & $\begin{array}{l}\text { Viral load/response to interferon therapy } \\
\mathrm{HDV} \text { viraemia }\end{array}$ & $31-33$ \\
\hline & HIV-1 & HIV-1 genomic RNA & $\begin{array}{l}\text { HDV viraemia } \\
\text { Viral load correlates with disease stage }\end{array}$ & $\begin{array}{l}34 \\
22,23\end{array}$ \\
\hline & & & Relative infected cell burden & \\
\hline & HPV & HIV-1 proviral DNA & Transition to replicative phase & 25 \\
\hline & HSV (genital) & HPV 16 DNA & Cervical invasive carcinoma & 35 \\
\hline \multirow{4}{*}{ bacterial } & Salmonella enteriditis & Virulence plasmid DNA & $\begin{array}{l}\text { Vertical transmission to infant } \\
\text { Specific identification and quantification in broth cultures }\end{array}$ & 36 \\
\hline & Meningitis & TNF $\alpha$, LT, IL-1 & Monitoring cytokine response in CSF & 38 \\
\hline & Mycobacterium leprae & $\mathrm{IL}-2, \mathrm{INF} \gamma$ & $\mathrm{T}_{\mathrm{H}} 1$ (tuberculoid) versus & \\
\hline & $\mathrm{cm}^{\circ}$ & IL-4,5,10 & $\mathrm{T}_{\mathrm{H}} 2$ (lepromatous) response & \\
\hline \multirow{8}{*}{$\begin{array}{l}\text { parasitic } \\
\text { Cancer }\end{array}$} & Trypanosima cruzi & Kinetoplast (k) DNA & Estimation of parasitaemia & 40 \\
\hline & Amplified oncogenes & $\begin{array}{l}c-e r b B 2 \\
N-m y c\end{array}$ & $\begin{array}{l}\text { Breast cancer } \\
\text { Neuroblastoma }\end{array}$ & 19 \\
\hline & & EGFR & $\begin{array}{l}\text { Neurobiastoma } \\
\text { Glioma }\end{array}$ & $\begin{array}{l}19 \\
19\end{array}$ \\
\hline & & HER-2 & Ovarian cancer & 41 \\
\hline & Translocated oncogenes & $\mathrm{Bcl} 2(\mathrm{t}[14: 18])$ & Non-Hodgkin's lymphoma (residual disease) & 42 \\
\hline & Mutatic & $\begin{array}{l}\text { Bcr-Abl } \\
\text { Ki-ras }\end{array}$ & $\begin{array}{l}\text { Chronic myelogenous leukaemia } \\
\text { Premalignant lesion detection }\end{array}$ & 43 \\
\hline & Allele loss at & DCC, p53, Rbl, NF-1 & Colorectal carcinoma & 28 \\
\hline & Multidrug resistance & $\begin{array}{l}\text { MDR-1 mRNA } \\
\text { (P-glycoprotein) }\end{array}$ & Prediction of resistance/susceptibility to certain drugs & $1,2,12$ \\
\hline \multirow{2}{*}{$\begin{array}{l}\text { Inflammation } \\
\text { inflammatory bowel } \\
\text { disease } \\
\text { glomerulonephritis }\end{array}$} & Cytokine expression & MCP-1 mRNA & Upregulation in inflammatory bowel disease & 45 \\
\hline & $\begin{array}{l}\text { Renin-angiotensin system } \\
\text { function }\end{array}$ & Renin mRNA & Early decrease in renin expression & 46 \\
\hline $\begin{array}{l}\text { Transplation } \\
\text { transplant rejection/ } \\
\text { tolerance }\end{array}$ & Bone marrow transplant & $\begin{array}{l}\text { Microsatellites } \\
\text { IL-10 mRNA }\end{array}$ & $\begin{array}{l}\text { Evaluation of mixed chimerism } \\
\text { Tolerance to HLA mismatched haematopoietic stem cells in } \\
\text { SCID }\end{array}$ & $\begin{array}{l}26 \\
47\end{array}$ \\
\hline \multirow{2}{*}{$\begin{array}{l}\text { Genetic disease } \\
\text { thalassaemia } \\
\text { muscular dystrophy } \\
\text { Down's syndrome }\end{array}$} & & \multirow{2}{*}{$\begin{array}{l}\text { Hb } \beta A \text { } v \text { Hb } \beta S \text { mRNA } \\
\text { Dystrophin mRNA } \\
\text { microsatellites }\end{array}$} & Relative expression levels in heterozygotes & $\begin{array}{l}48 \\
49\end{array}$ \\
\hline & Trisomy 21 & & Antenatal screening of fetal cells in maternal blood & 50 \\
\hline
\end{tabular}

$\mathrm{CMV}=$ cytomegalovirus; $\mathrm{EBV}=$ Epstein-Barr virus; $\mathrm{HBV}=$ hepatitis $B$ virus; $\mathrm{HCV}=$ hepatitis $C$ virus; $H D V=$ hepatitis $D$ virus; $H P V=$ human papillomavirus; $\mathrm{HSV}=$ herpes simplex virus; $\mathrm{MDR}=$ multidrug resistance; $\mathrm{TNF}=$ tumour necrosis factor; $\mathrm{IL}=\mathrm{interleukin} ; \mathrm{EBNA}=\mathrm{EBV}$ associated nuclear antigen; $\mathrm{LT}=$ heat labile toxin; EGFR = epidermal growth factor receptor; $\mathrm{INF}=$ interferon; $\mathrm{CSF}=$ cerebrospinal fluid.

with an endogenous non-competitive standard. These situations lend themselves to the use of multiplex PCR reactions. In these multiplex PCR reactions multiple genes are amplified with primer sets that are often individually labelled with different coloured fluorescent markers. This technique permits the rapid and cost-effective assay of multiple parameters from a given sample (for example, allele loss at a range of oncosuppressor loci in colorectal cancer $^{28}$ ).

Absolute quantitation - that is, expression of the level of target sequence per unit of a sample (for example, numbers of molecules per $10^{6}$ cells, per $\mathrm{ml}$ of blood, per $\mathrm{mg}$ of tissue, etc.), is required in virological and other situations. In these cases some form of competitive PCR assay is often used.

There are now many reports of the use of qPCR in all aspects of clinical practice. A summary of some of these reports is presented in the table.

\section{Conclusion}

Advances in PCR technology and the application of internal and exogenous amplification standards, together with the novel amplimer detection methods have revolutionised molecular quantitation in the clinic. The power of the PCR as a quantitative measure of molecular parameters in clinical disease has been recognised and qPCR technology is poised to be a powerful diagnostic tool.
RDGM is a Medical Faculty Scholar. This work was supported by RIE NHS Trust and Scottish Office Biomedical Research Committee.

1 Murphy LD, Herzog CE, Rudick JB, Fojo AT, Bates SE. Use of the polymerase chain reaction in the quantitation 2 Noonan KE, Beck C, Holzmayer TA, Chin JE, Wunder JS, Andrulis IL, et al. Quantitative analysis of MDR1 (multidrug resistance) gene expression in human tumours by polymerase chain reaction. Proc Natl Acad Sci USA 1990;87:7160-4.

3 Park O-K, Mayo KE. Transient expression of progesterone receptor messenger RNA in ovarian granulosa cells after the preovulatory luteinising hormone stage. Mol Endocrinol 1990;5:967-78.

4 Razin E, Leslie KB, Schrader JW. Connective tissue mast cell in contact with fibroblasts expresses IL-3 mRNA: Analysis of single cells by

5 Cantlay AM, Smith CAD, Wallace WA, Yap P-L, Lamb D, Harrison DJ. Heterogeneous expression and polymorphic genotype of glutathione S-transferases in human lung. Thorax 1994;49:1010-4.

6 Miens C. A simple, rapid method for isolating RNA from paraffin-embedded tissues for reverse-transcription-polymerase chain reaction (RT-PCR). $f$ Histochem Cytochem 1994;6:811-13.

7 Siebert PD, Larrick JW. Competitive PCR. Nature 1992; 359:557-8.

8 Raemakers L. Quantitative PCR: Theoretical considerations with practical implications. Anal Biochem 1993;214:582-5.

9 Wang AM, Doyle MV, Mark DF. Quantitation of mRNA by the polymerase chain reaction. Proc Natl Acad Sci USA by the polymerase

10 Becker-André M, Kahlbrock K. Absolute mRNA quantification using the polymerase chain reaction (PCR). A novel approach by a PCR aided transcription titration assay (PATTY). Nucleic Acids Res 1989;17:9437-46.

11 Gilliland G, Perrin S, Blanchard K, Bunn HF. Analysis of cytokine mRNA and DNA: detection and quantification by competitive polymerase chain reaction. Proc Natl Acad Sci USA 1990;87:2725-9.

12 de Kant E, Rochlitz CF, Herrmann R. Gene expression analysis by competitive and differential PCR with antisense competitors. Biotechniques 1993;17:934-42.

13 Natarajan V, Plishka RJ, Scott EW, Lane HC, Salzman NP. An internally controlled virion PCR for the measurement of HIV-1 RNA in plasma. PCR Methods Appl 1994;3: 346-50. 
14 Siebert PD, Larrick JW. PCR MIMICS: Competitive DNA fragments for use as internal standards in quantitative PCR. Biotechniques 1993;14:244-9.

15 Gause WC, Adamovicz J. The use of the PCR to quantitate gene expression. PCR Methods Appl 1994;3:S123-35.

16 Ferre F. Quantitative or semiquantitative PCR: reality versus myth. PCR Methods Appl 1992;2:1-9.

17 Crotty PL, Staggs RA, Porter PT, Killen AA, McGlennen RC. Quantitative analysis in molecular diagnostics. Hum Pathol 1994;25:572-9.

18 Svetic A, Finkelman FD, Jian YC, Dieffenbach CW, Scott $\mathrm{DE}, \mathrm{McC}$ arthy KF, et al. Cytokine gene expression after in vivo primary immunisation with goat antibody to mouse IgD antibody. F Immunol 1991;147:2391-7.

19 Kondo S, Kono T, Sauder DN, McKenzie RC. IL-8 gene expression and production in human keratinocytes and their modulation by UVB. F Invest Dermatol 1993;101: 690-4.

20 Frye RA, Benz CC, Liu E. Detection of amplified oncogenes by differential polymerase chain reaction. Oncogene 1989 ; 4:1153-7.

21 Chou O, Russel M, Birch DE, Raymond J, Bloch W. Prevention of PCR mispriming and primer dimerisation improves low copy-number amplifications. Nucleic Acids Res 1992;20:1713-23.

22 Aoki-Sei S, Yardman R, Kageyama S, Hoekzema DT, Pluda JM, Wyvill KM, et al. Plasma HIV-1 viremia in HIV-1 infected individuals assessed by polymerase chain reaction AIDS Res Hum Retroviruses 1992;8:1263-70.

23 Piatak M Jr, Saag MS, Yong LC, Clark SJ, Kappes JC, Luk $\mathrm{K}-\mathrm{C}$, et al. High plasma levels of HIV-1 in plasma during all stages of infection determined by competitive PCR. Science 1993;259:1749-54.

24 Kellogg DE, Sninsky J, Kwok S. Quantitation of HIV-1 proviral DNA relative to cellular DNA by the polymerase proviral DNA relative to cellular DNA by the pol

25 Jurriaans S, De Ronde A, Dekker J, Cornelissen M, Goudsmit J. Increased number of single-LTR HIV-1 DNA junctions correlates with HIV-1 antigen expression and CD4 + cell decline in vivo. $\mathcal{F}$ Med Virol 1995;45:91-8.

26 Lawler M, Humphries S, McCann SR. Evaluation of mixed chimerism by in vitro amplification of dinucleotide repea sequences using the polymerase chain reaction. Blood 1991;77:2504-14.

27 Boivin G, Olson CA, Quirk MR, St Cyr SM, Jordan MC. Quantitation of human cytomegalovirus glycoprotein $\mathrm{H}$ gene in cells using competitive PCR and a fluorescencegene in cells using competitive PCtection system. F Virol Methods 1995;51:329-42.

28 Cawkwell L, Lewis FA, Quirke P. Frequency of allele loss of DCC, p53, RB1, WT1, NF1, NM23 and APC/MCC in colorectal cancer assayed by fluorescent multiplex polymerase chain reaction. $\mathrm{Br} \mathcal{F}$ Cancer 1994;70:813-18.

29 Riddler SA, Breing MC, McKnight JLC. Increased level of circulating Epstein-Barr virus (EBV)-infected lymphocytes and decreased EBV nuclear antigen antibody responses are associated with the development of posttransplant lymphoproliferative disease in solid-organ transplant recipients. Blood 1994;84:972-84.

$30 \mathrm{Wu}$ J, Sullivan DE, Gerber MA. Quantitative polymerase chain reaction for hepatitis B DNA. $\mathcal{F}$ Virol Methods 1994 ; 3:331-41.

31 Du Bois DB, Gretch D, Dela Rosa C, Lee W, Fine J, Blagg CR, Corey L. Quantitation of hepatitis C viral RNA in sera of hemodialysis patients: Gender-related differences in viral load. Am $\mathcal{F}$ Kidney Dis 1994;24:795-801.

32 Gretch D, Corey L, Wilson J, Dela Rosa C, Willson R Carithers $\mathrm{R} \mathrm{Jr}$, et al. Assessment of hepatitis $C$ virus RNA levels by quantitative competitive polymerase chain reaction: High-titre viremia correlates with advanced stage of disease. F Infect Dis 1994;169:1219-25.

33 Hino K, Okuda M, Konish T, Ishito H, Okita K. Serial assay of hepatitis $C$ virus RNA in serum for predicting response to interferon-alpha therapy. Dig Dis Sci 1995;40:14-20.
34 Deny P, Fattovich G, le Gal F, Guistina G, Lecot C, Morisca G, et al. Polymerase-chain-reaction based semiquantification of hepatitis $D$ viraemia in patients treated with high doses of alpha $2 \mathrm{~b}$ interferon. Res Virol 1994;5: 287-95.

35 Kinoshita M, Shin S, Aono T. A sensitive and quantitative method for the determination of number of HPV16 DNA copies by using the competitive polymerase chain reaction. Genet Anal Tech Appl 1993;10:116-21.

36 Cone RW, Hobson AC, Brown Z Ashley R, Berry S, Water $\mathrm{C}$, Corey $\mathrm{L}$. Frequent detection of genital herpes simplex virus DNA by polymerase chain reaction among pregnan women. $\mathcal{F} A M A$ 1994;272:792-6.

37 Wood MW, Mahon J, Lax AJ. Development of a probe and PCR primers specific to the virulence plasmid of Salmonella enteritidis. Mol Cell Probes 1994;6:473-9.

38 Rieckmann P, Albrecht $M$, Ehrenreich $H$, Weber $T$, Michel U. Semi-quantitative analysis of cytokine gene expression in blood and cerebrospinal fluid by reverse transcriptase polymerase chain reaction. Res Exp Med 1995;195:17-29.

39 Yamamura M, Uyemura K, Deans RJ, Weinberg K, Rea $\mathrm{TH}$, Bloom BR, et al. Defining protective responses to TH, Bloom BR, et al. Defining protective responses to pathogens: cyto

40 Centurion-Lara A, Barrett L, Van Voorhis WC. Quantitation of parasitemia by competitive polymerase chain reaction amplification of parasite $\mathrm{kDNA}$ minicircles during chronic infection with Trypanosoma cruzi. F Infect Dis 1994;170 1334-8.

41 Dobianer K, Hruza C, Ehrlich G, Sevelda P, Czerwenka K, Soreq $\mathrm{H}$, et al. HER-2 amplification but not butyrylcholinesterase mutability reflects aggressiveness of European-originated ovarian tumours. Gynecol Oncol 1995;56:200-6.

42 Hetn F, Contlee F, Roy DC. A non-isotopic nested polymerase chain reaction method to quantitate minimal residual disease in patients with non-Hodgkin's lymphoma. Mol Cell Probes 1994;8:449-57.

43 Lion T. Clinical implications of qualitative and quantitative polymerase chain reaction analysis in the monitoring of patients with chronic myelogenous leukemia. Bone Marrow Transplant 1994;14:505-9.

44 Mitchell CE, Belinsky SA, Lechner JF. Detection and quantitation of mutant K-ras codon 12 restriction fragments by capillary electrophoresis. Anal Biochem 1995; 224:148-53.

45 Reinecker HC, Loh EY, Ringler DJ, Mehta A, Rombeau $\mathrm{JL}$, MacDermott RP. Monocyte-chemoattractant protein 1 gene expression in intestinal epithelial cells and in flammatory bowel disease mucosa. Gastroenterology 1995; 108:40-50.

46 Wagner J, Drab M, Gehlen F, Langheinrich M, Volk S, Gauten D, Ritz E. PCR analysis of human renal biopsies: Renin gene regulation in glomerulonephritis. Kidney Int 1994;6:1542-5.

47 Bacchetta R, Bigler M, Touraine JL, Parkman R, Tovo PA, Abrams $\mathrm{J}$, et al. High levels of interleukin 10 production in vivo are associated with tolerance in SCID patients transplanted with HLA mismatched hemopoietic stem cells. Ұ Exp Med 1994;179:493-502.

48 Dimovski AJ, Efremov DG, Gu LH, Huisman THJ. The relative levels of beta (A) and beta (S) mRNAs in $\mathrm{Hb} \mathrm{S}$ heterozygotes and in patients with $\mathrm{Hb} \mathrm{S}$-beta +-thalheterozygotes and in patients with $\mathrm{Hb} \mathrm{S}$-beta + -thal-
assaemia or $\mathrm{Hb} \mathrm{S}$-beta $+-\mathrm{HPFH}$ combinations. $\mathrm{Br} f$ assaemia or $\mathrm{Hb} \mathrm{S}-$ - beta

49 Abbs S, Bobrow M. Analysis of quantitative PCR for the diagnosis of deletion and duplication carriers in the dystrophin gene. F Med Genet 1992;29:191-6.

50 Mansfield ES. Diagnosis of Down's syndrome and other aneuploidies using quantitative polymerase chain reaction and small tandem repeat polymorphisms. Hum Mol Genet 1993;2:43-50. 